\title{
Correction to: Impaired adult neurogenesis is an early event in Alzheimer's disease neurodegeneration, mediated by intracellular $A \beta$ oligomers
}

\section{Chiara Scopa - Francesco Marrocco - Valentina Latina - Federica Ruggeri - Valerio Corvaglia - Federico La Regina • Martine Ammassari-Teule · Silvia Middei · Giuseppina Amadoro · Giovanni Meli · Raffaella Scardigli •}

Antonino Cattaneo

Published online: 2 January 2020

(c) The Author(s), under exclusive licence to ADMC Associazione Differenziamento e Morte Cellulare 2020

\section{Correction to: Cell Death \& Differentiation} https://doi.org/10.1038/s41418-019-0409-3

Since the publication of the original article, the authors have noticed that in "Acknowledgements" section the following funding Statement was erroneously missing:
"CS was recipient of a MIUR fellowship for the PhD program in Molecular, Cellular and Environmental Biology at the Department of Science, University Roma Tre (Supervisor Prof. Sandra Moreno)".

This has now been corrected in both the PDF and HTML versions of the paper. The authors apologize for any inconvenience this may have caused. 